\title{
宿題報告 II
}

\section{異常 蛋 白 血 症

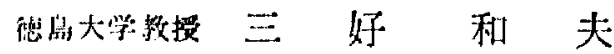

はじめに

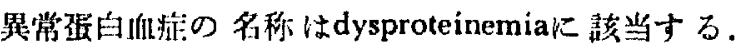
dysproteinemiaは, はじめWuhrmann, Wunderley Tiselius電筑胁動像に㧍けるアルブミン，各種グロブリ ンの成分比率の簧常に対して用いたもので代態あるいは 所見の名称である，演者は，今回，異常蛋白血症の名称 を，上り広く，血液蛋白質の異常を来たす疾患群すなわ ち疾患名と解积して述べる。すなわち演者の提晹してき た，血液蛋白病blood protein disease とほぼ同義語とし

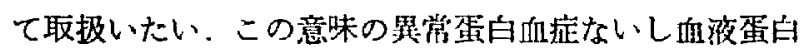
满とは，血湤蛋白質の变化が，ての疾患の本態もしくは 主要所見であるごとき疾忠群の意味である。なお，血浆 には無数の蛋白質があるがここでその異常を論じるの は，その主要成分major componentすなわちでルブミ ン，線維素源と免疫グロブリンについてである．

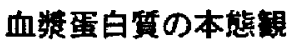

近年に和ける蛋白質研究の進展は目覚しく，殊に，特 殊な蛋白質，例えば血色素やミオグロビンまたインスリ ンの分子棈造の決定，さらに，これと选伝子の結びつき に対する解明によつて，いわゆる分子生物学が確立され たといつてよい.

血奖蛋白質は，これら単䋁ですでにその棰造の明らか にされた蛋白質と，梖雑でなお末解決の細胞や組蟣蛋白

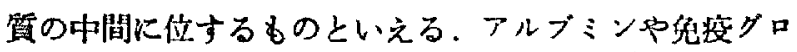
ブリンについてい前のようにこれらを漠然とした䍿質 溶液と考之る時代は過ぎ，すでに，それぞれが固有の分 子量を有与る蛋白犋の集団である，すなわち，分子生物 学的に考察されるべき段階にたち至つている.

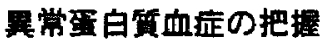

異常蛋白質血症は，早くより，臨床医がその多くな， 臨沫庭状（浮腫や感染の多発その他）や赤沈の促進，血 清想質反応あるいは，血港蛋白質の産生細胞及びそれに

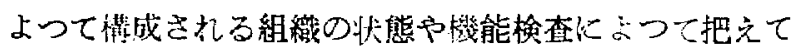
きたところである。

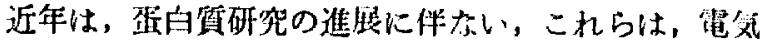

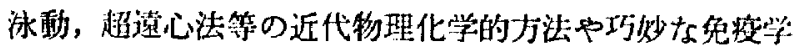

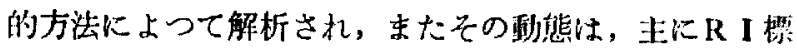

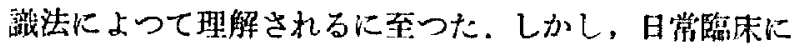
あたつて，㴒沈その他によるこれら症例のスクリーニン グは必要である。各時代に応じて活用された血禁蛋白質 異常の把握法の相互関保について述へる。.

\section{血䄅蛋白缶異常の発現機序}

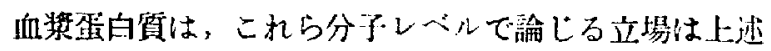
のごとくであるが，生体内におこる证態発玩の機序は， 大きく、つきのごとく分汁られる。门，遗层子（構造

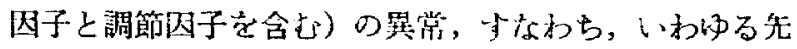

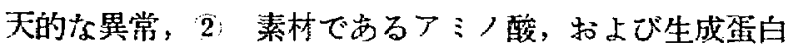
質の出納 (供給・吸収障害, If管外消失等), (3) 産生 細胞の病態，アルブミンに関しては，主として肝科胞障 害，㲥疫グロブリンに関しては，抗原に対する細胞の多 彩な增殖 (多彩なグロブリンの産生).

\section{アルブミンの構造と不均一性}

此較的均一度の高いフルプミンも近年遭伝性のdouble albuminemiaの発見によつて研究の大きな足場をえてい ろ.アルブミンの遗伝子には対立遗伝子のAln, Alsl, Alra があるらしい，具体的に本邦症例について述べる.

また，演者らがいくつかの研究成結によつて主韭して いるとト胎愳型アルブミン(Alb F)は，成人アルブミン (Alb A) に対して抵抗性を有し，また, hydroxylapatite カラム等によるsubunitの成分比が異なること,さらに， 罢珄化平衡現象において, 闻アルブミンの異性化曲線は 一政せず，フルブミン分于に結合する水㨞イオン数がス れぞれ異なることで特珙である。.Alb F出座後 4 力月 頃までに，恰すHb FがHb Aに路换るのと平行して Alb Ak入机換る。このAlb Fを例として，フルブミン のsubunitに関連すると思われる 不均一性の問題を論じ 方.

兔瘵グロブリンの構造と不均一性

臨休例に括ける兔疫グロブリンは単一ではないまず， 
免孜グロブリソの種類には主要成分として IgG, IgA， IgM等あるが，これらは，感染，感作等の增加時，また， 無ガンーグロブリン血症等の減少時にも, それぞれ独特 の热但を示す(その項参照)。つぎにこれら個々の免疫グ ロブリンは，云れぞれ易動度や抗体活性を異にする多数 のダロブリンから成立している。これが一般に見られる polyclonal（多クローン性）な统疫グロブリンのあり方 に他ならない，そしてこの際，その棈成分light chain

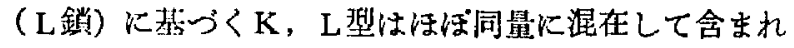
ている。

免度グロブリンは，しかし，特殊な疾患，骨䯣腫やマ クログロブリン血症では，特定のグロブリンのしかも monoclonal (単クローン性) な增加がみられる.すなわ ち， G，A骨髉腫等で，このような場合，堌加グロプリ ソは，易動度の上でむ均一度が高く鋭いピークとしてみ られ，また，上記 K型，L型に関してる号の何れかに片 寄つてみられる(症例の項参照).

なお, 角疫グロブリンに関しては, その構成polypeptide chainである light chainやheavy chain (H鎖)の 両者にも，前者は10コ，後者は的15コ のsubunitの存在 がみられる。それらの組合せによつて多数の異なつた免 疫グロブリンの生じることが理解される。

これらの論議は，学問的には免疫グロブリンの棈造論 に他ならないが，その論拠の多くが臨床例にみられる異 常所見よりえられたるのである。

\section{異常蛋白血症（血液蛋白病）の型と代表症例}

蛋白病Protein Disease：A 血液蛋白病，I 栄養不足 型，【蛋白脱出型（ネファーゼ型），肝障害型(肝硬変 型)，W感染・感作型，V翏原病型（エリテマトーデス 型)，V本態不明の高グロブリン血症，Wマクログロブリ ン血症型，谓異種蛋白增加型(骨髄腫型)， X蛋白久泛異常 型, hypoproteinemia, analbuminemia, fetal albumin, double albuminemia, afibrinogenemia, agammaglobulinemia, etc. B血友病ならびK類縁疾患，C異常血色素 症，D異常ミオグロビン症，E異常醉素症，F異常ホル モン症。

上は，演者の考えで血装蛋白質を含めて，広く体蛋白 睤の病熊を䨞白病として総括し，これを演者の考党で分 類したものである.今回は，この中の血液蛋白病について 述べる，血渡蛋白病関豆る各型の分類は，その成立機 序を主として考え，異常蛋白質の種類を加味して行なつ たものである．九つの基本型のらち，原因的には，I栄荃
不足型，II 蛋白脱出型， 两 肝障害型，IV 感染・感作型 は，二次的の変化といつてよい（四の肝障害型にはなお 不明の点が多い)，V翏原病型以下の原因は不明である。

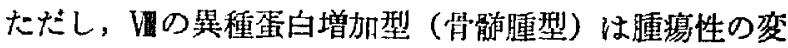
化とみられるし，また【Xの蛋白欠乏買常型は家族的に発 現与ることが多く遗伝体筫的疾患である。

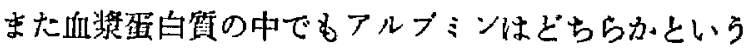
之物質的，栄浑的な存在であるが免疫グロブリンは，個 性的で，それぞれの個体に特鼠的で方る。两者の报い方 にも，これらの性格を考磨子る要がある。遗伝，体貿的 な異常はしかしこれら両渚にみられる。

まず，アルブミンに開し，」，，四は，これを主に turn overの面から朓める (その項参照). 先疫グロブリ ンK関し， I U（圆䀒硬変症は，アルブミンの産生障 責と免疫グロブリンの增加の耐者で特銜づけられる) は，いわゆるpolyclonalの免疫グロブリンの增加， IXはmonoclonalな增加ということができる。

Polyclonalの增加に関しては，各種允疫グロブリン (IgG, IgA, IgM等)は疾患の状態炕よつて， ある程度の 法則に従つて変動する(Agar plate法で定量検討).そし て感染・感作の末期で柱にIgGの固定した增加status hyperglobulinemicus(演者)ともいらべき状態がみられ る.本態不明の高グロブリン血症purpura hyperglobulinemica, splenomegalia hyperglobulinemica, さらた, この間，特殊な例に時火みられるmonoclonalな增加も このよらな状態と関連して考えるべきかも知れない。

Monoclonal增加については，マクログロブリン血症 (本邦で現在16〜20列の経験報告がある), 骨䯣腫(同し く800〜1000例）を中心として，特に後者について，

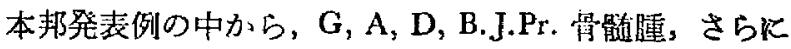
その L型，K型等について述べ，また，これら症例にお ける尿中へのlight chainやheavy chain, その他micromolecular proteinの排出について論じる.

蛋白欠乏異常型についても， analbuminemia (Bennholdの例以外にない）除いて，本邦で百殆亡゙の例が 経験されるに至つた，家族的hy poproteinemia $2 \sim 3$ 家 系, double albuminemia $3 \sim 4$ 家采, A(hypo-) fibrinogenemia10 15例, agammaglobulinemia, Bruton型10 15例, ataxia teleangiectasia 6 例, Swiss型 $1 \sim 2$ 例等で ある.

これらの症例の代表例を原著者の厚意によつて要約紹 
介したい。

\section{血斿虫白留のturn over}

RISAを用いての成精に基づいてえた half time( $\left(T^{1 / 2}\right)$ ， exchangeable albumin pool, albumin turnover rate $\% 1$ day, g/day, g/kg/dayその他について檤べる. 例充ば， アルブミンに関しては壮1/2はコントロール例11.6日（以 下いずれす平均倠）に対し，蛋白脱出型では4.0日と短

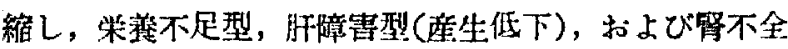

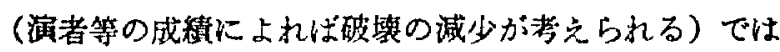
モれでれ13.6，16.0，17.0日と延舆する。たたし低蛋白 血症の一つ, いわゆる protein-losing gastroenteropathy ではT褯は 6.4日よ短維するがturnover rate $\mathrm{g} / \mathrm{kg} / \mathrm{day}$ は0.18gで, ニントロール $(0.28 \mathrm{~g})$, ネフローせ症候群 $(0.29 \mathrm{~g})$ に比して少なく，肝硬变 $(0.16 \mathrm{~g})$, 吸收障害 例 $(0.15 \mathrm{~g})$ のそれに近いすすなわち本症の多くではそ れらの成績に基ふいて，その成立に胃晹筞への蛋白質脱 出のみならす゚吸収障害中生成障害の因子の加わつている ことが考えられる。

免疫グロブリンK関しては， ${ }^{31} I-I g G の T^{1 / 2}$ はコント ロール例で16.3日, turnover rate \%/dayは $4.2 \%$ であ る。蛋白病のうちたと光ばG-myelomaでは T/2は $6.4 \%$ と短縮し，turnover rate％/dayは10.8\% と增加する。 またいずれる高いIgG伹症を呈する肝硬変，SLE，慢 性関節リウマチなどです T1/2はそれぞれ12.0，7.0,9.0 日と短樎しturnover rate \%/dayは增加する。 しかしAmyelomaにおいてIgGのT1/2は16.8日, turnover rate\% dayは 4.1\%で正裳域内にある，すなわらIgGについて

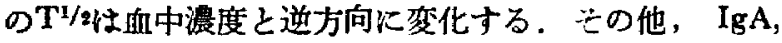
IgMについて模索した成續についてるられる。しかし線 維素原についてはこのよらな関係はみられない。これは 凝血障害のある血友病に関してる同様でする。

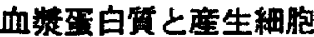

細胞の蛋白質産生に関し，これをメジウムに放出する 細胞は，内部構造において粗面小胞体とゴルシ体の発達 で特数づけられた，いわゆる分泌細胞である．血桨蛋白 犋の库生細胞としては，フルブミン（加えて線維素原） は肝細胞，免度グロブリンのうちIgG，IgAは形質細胞 系であることがすで確立された。しかし，IgMの産生 紐胞はlymphocytoid cellとされている段階で詳种はな お不明である。

この間の問題に関し，著者らの主に臨床例における垬 験成績を含めて述べる，特に今回は，相細胞，骨髄腫細
胞，末梢血培養リンパ球等(いずれる人体)の破壊抽出蛋 白質をアルプミンや各種兔疫グロブリンに対する抗血清 によつて検した成精について述べる。またこれら蛋白質 産生細胞の組織内におけるcell cycleの有様を検討（演 者らの考案したDNA曲線の解析に上る）した結果，蛋 白質産生は，それぞれの細胞の成熟段階における特殊機 能として行なわれるとの見解を述べる。

偱床例における免疫グロブリンと抗体活性

ヒトにみられる各種の免疫执体る充疫グロブリンに他 ならないが，既述，臨床例に增加してみられるpolyclonal 及びmonoclonalな免疫グロブリンが，特定の抗原に対す る抗体的活性を有するか否か佯らかでない。

この問題に関し，諸家の実験成續に演者のものも併せ て考察を加えたいが，結論的にはmonoclonalな增加は 特殊な単一抗原の存在に基因するにしても，その異常な 高度增加の意味において，またpolyclonalな增加は，は じめの主要抗原以外の抗原（自己体内で非自己化した抗 原に対するいわゆる自己免疫の状熊も含むか子知九な い）に対するグロブリンとして，いずれる，その個体に 有利なるのではないと考竞たい。

\section{異常蛋白咀症の症状と所見}

異常蛋白血症として，実際臨床上最も多く遭遇する変 化は、アルブミンの隇少之免疫グロブリンの增加（血奖 蛋白質の左方移動）である。しかし，この際增加するグ ロブリンは正常免疫グロブリンの活性楼能を果さない場 台が多い，才なわち，異常蛋白血症そのものによる症状 は，一般にアルブミソの娍少に基づく血液翏在の低下 による全身の浮腫（下痢を伴なう場合もむる）扣よび全 身の策盖障害と，先疫グロブリンの正常機能低下に基づ く感染の症状でかる、また加えて，粗大蛋白質增加によ る小血管に約ける偱環障害，また身体組織，臟器への沈 着等によるるのである。

bちろん实際上は，この他，各種蛋白病の病因関連 する幾多の症状が伴なつてみられる。

埗状の総括：全身浮腄，赤沈促進（閦質反応の陽性

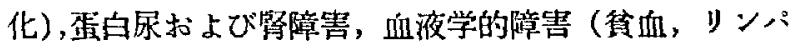

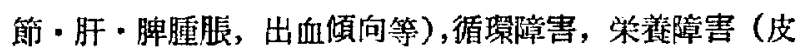
筒，爪，毛管等)，眼底異常所見，扣よび感染症状(防御 機能低下，体液抗体欠乏の他炕しばしばいかける細胞性 防倁機能子低下する)。

\section{むすび}

異常蛋白血症を血挦蛋白質の変化がその本態あるいは 
主要症状であるごとき疾忠群の病名と理解して述べる。 これを演者は血液惩白病と呼んでいる。 血浆蛋白質は，遗伝子に险定されて生合成され，固有

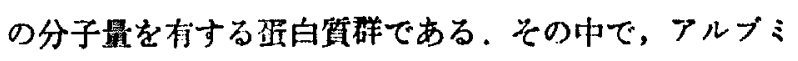
ンはより秦忉的で単純であるが，允疫クロン゙リンは，湖 性的で，暴なつた抗原の标在で多彩の免度活性を有与る。

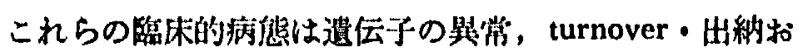
よび産生細胞の病隹 (障書, 增㱷) の各レベルで論じら れる要がある。これが各佳々の症例に和ける臨床医の病
状の判断であり診断過程に他ならない，

以上の諸問題を尃ら臨床の具体例をあけ゚て述べる。血 㓋蛋白質ひいては一般蛋白質の知見の閒発は，これら臨

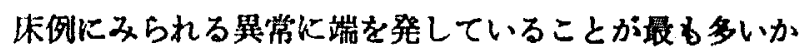
らである。

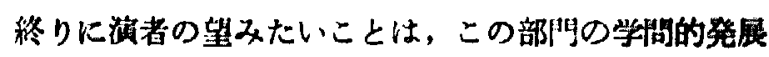

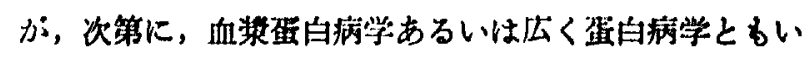
らべきののに形成されていくことである。 